\title{
Глагольный залог в якутском и тувинском языках в сопоставлении с монгольскими и тунгусскими языками
}

\author{
Надежда И. Данилова \\ Институт гуманитарных исследований и проблем малочисленных народов Севера СО РАН, \\ Российская Федерация
}

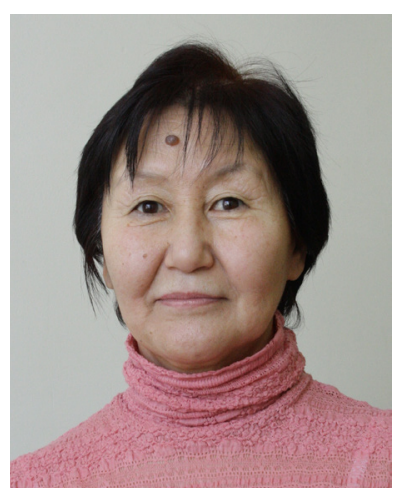

В статье обсуждаются залоговые формы глагола, их семантическая структура и оформляемые на их базе синтаксические конструкции, представленные в исследованиях по тюркским, монгольским, тунгусским языкам. В настоящее время исследование данных глагольных образований вплотную связано с актуальной проблемой системных связей формальной морфологии и грамматической семантики.

Вопрос определения залога получал неоднозначную трактовку и вызывал дискуссии на всем протяжении истории изучения тюркских языков. В рассматриваемых языках представлен почти одинаковый набор грамматических форм залога: основного (или действительного), страдательного, взаимного (или совместно-взаимного), понудительного, возвратного. Языки каждой группы алтайских языков оперируют одним и тем же аффиксом залоговых форм или его алломорфами. Например, в монгольских языках побудительный залог образуется при помощи одного суффикса -уул, в тунгусо-маньчжурских языках каузатив представлен аффиксом, восходящим к форманту *-вукан-/укан, тюркские используют варианты аффикса -m( $\left(^{\circ}\right)$. Характерной чертой алтайских языков является общность семантики каждой залоговой формы в них. Например, функция побудительного залога определяется как выражение вмешательства одного субъекта в действие другого. Языки алтайской типологии в целом совпадают в области синтаксического представления залоговых отношений.

В анализируемых языках синтаксические конструкции с залоговой семантикой оформляются в зависимости от переходности/непереходности исходной глагольной основы и семантических типов актантов ситуации. Глагольный залог требует дальнейшего исследования как грамматическая форма и основанная на ней семантическая категория залоговости.

Ключевые слова: алтайские языки; тюркские языки; монгольский язык; тувинский язык; эвенский язык; эвенкийский язык; глагол; залог; аффикс; конструкция

Для цитирования:

Данилова Н. И. Глагольный залог в якутском и тувинском языках в сопоставлении с монгольскими и тунгусскими языками [Электронный ресурс] // Новые исследования Тувы. 2020, № 1. URL: https://nit.tuva.asia/nit/article/ view/906 (дата обращения: дд.мм.гг.). DOI: 10.25178/nit.2020.1.12

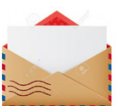

Данилова Надежда Ивановна - доктор филологических наук, заведующая отделом якутского языка Института гуманитарных исследований и проблем малочисленных народов Севера СО РАН. Адрес: 677027, Россия, г. Якутск, ул. Петровского, д. 1. Тел.: +7 (4112) 35-49-96. Эл. адрес: nadiv2008@mail.ru

ORCID ID: 0000-0003-3542-8448

Danilova Nadezhda Ivanovna, Doctor of Philology, Head, Yakut language Department, Institute for Humanities Research and Indigenous Studies of the North, Siberian Branch, Russian Academy of Sciences. Postal address: 1 Petrovsky St., 677027 Yakutsk, Russian Federation. Tel.: +7 (4112) 35-49-96. E-mail: nadiv2008@mail.ru 


\title{
Verbal voice in Yakut and Tuvan languages in comparison with Mongolian and Tungus languages
}

\author{
Nadezhda I. Danilova \\ Institute for Humanities Research and Indigenous Studies of the North, Siberian Branch, Russian Academy of Sciences, \\ Russian Federation
}

\begin{abstract}
The article examines voice forms of the verb, their semantic structure and syntactic constructions they give rise to, as seen in the studies of Turkic, Mongolian and Tungus languages. At the moment a study of these verbal forms is closely connected to the urgent issue of systemic links between formal morphology and grammatical semantics.

A variety of definitions of grammatical voice has been provided throughout the whole history of studying Turkic languages, generating incessant discussions. The languages in question feature almost the same set of voice forms: active, passive, reciprocal, imperative and reflexive. In every group of Altai languages, the same affix of voice forms, or its allomorphs, is functional. For instance, the imperative voice in Mongolian languages is formed by the suffix-uul, while in Tungus-Manchurian languages the causative features an affix etymologically stemming back to the *-vukan/-ukan formant, and the Turkic languages rely on different versions of the $-t\left({ }^{\circ}\right) r$ affix. An important feature of Altai languages is that all voice forms therein have common semantics - for instance, the imperative voice is seen as one subject interfering with the action of another. Languages of the Altai type largely overlap in how voice relations are syntactically presented.

In the languages under analysis, syntactic constructions with the meaning of grammatical voice take shape in accordance with transitive/intransitive character of the verbal stem and the semantic type of the situational actant. The verbal voice thus invites further study as a grammatical form and a carrier of voice as a semantic category.
\end{abstract}

Keywords: Altai languages; Turkic languages; Mongolian language; Tuvan language; Even language; Evenski language; verb; voice; affix; grammar construction

\section{For citation:}

Danilova N. I. Verbal voice in Yakut and Tuvan languages in comparison with Mongolian and Tungus languages. The New Research of Tuva. 2020, № 1. URL: https://nit.tuva.asia/nit/article/view/906 (access date ...). DOI: 10.25178/nit.2020.1.12

\section{Введение}

Залоговые формы глагола с разнообразным семантическим содержанием, о которых пойдет речь, имеются во всех современных алтайских языках и зафиксированы еще в старых и древних письменных источниках. Статья опирается на данные о залогах глагола, их семантической структуре и оформляемых на их базе синтаксических конструкциях, представленных в исследованиях по тюркским, монгольским, тунгусским языкам. Это как общие труды по морфологии, так и отдельные статьи сравнительно-исторического и сопоставительного плана. При этом, сравнительно-исторический аспект изучения этого языкового явления целью статьи не предусмотрен. В задачи публикации входит выявление общих признаков и особенностей в способах выражения и семантической структуре залоговых отношений, выбранных форм методом сопоставления. Основанием сопоставления избрана система грамматических форм выражения залоговых отношений в тюркских языках, в особенности, тувинском. Сопоставительная интерпретация осуществляется при помощи методики параллельного анализа выбранных форм в трех языковых классификационных группах.

Актуальность исследования категории глагольного залога обусловлена тем, что к настоящему времени вопрос определения залога получал неоднозначную трактовку и вызывал дискуссии на всем протяжении истории изучения тюркских языков. Как известно, общей теоретической проблемой исследования залога в языках алтайской типологической группы остается вопрос его статуса в языковой 
системе. Дискуссии по этому вопросу были обусловлены недискретным характером залоговых форм они демонстрируют переходный случай между словообразованием и формообразованием. Кроме того, «обращает на себя внимание и то, что залоговые формы недостаточно регулярны, довольно часто выражают незалоговые значения грамматического характера (многократность, интенсивность, длительность действия) и сравнительно легко поддаются лексикализации. Иногда присоединение к глагольной основе залоговых аффиксов не изменяет ее исходного грамматического значения и не привносит дополнительных лексических оттенков» (Щербак, 1981: 102). Это касается глагольных форм залога во всех языках алтайской классификационной группы и вызывает большой интерес со стороны исследователей.

В статье впервые поставлена проблема морфологической и семантической соотнесенности залоговых форм глагола на материале трех алтайских языков. Как известно, ранее была более глубоко разработана проблема соответствий разного уровня внутри каждой группы: тюркской, монгольской, тунгусо-маньчжурской. Кроме того, в поле зрения алтаистов традиционно находились тюркомонгольские и тюрко-тунгусские языковые связи. Новым для сопоставительных исследований алтайских языков является метод глоссирования, который дает возможность объективного представления результатов анализа и доступа к данным для более широкого круга лингвистов. Глоссирование примеров выполнено в соответствии с предложенными Н. И. Винокуровой принципами поморфемного членения, которые могут быть пригодны для унифицированного использования при представлении данных алтайских языков, для которых типологически характерно использование агглютинативного способа грамматической деривации (Винокурова, 2016).

\section{Теоретические подходы к исследованию глагольного залога}

В алтаистике было широко распространено мнение о двойственной - лексико-грамматической природе категории залога. Такой точки зрения придерживался известный российский тюрколог С. Н. Иванов, который считал, что в залоговой форме ее «лексическая, словообразовательная сущность проявляется в том, что аффиксы производных основ образуют новые по сравнению с исходными основами лексические единицы, характеризующиеся новыми объектными связями (сочетаемость с дополнениями). Ее грамматическая, словоизменительная сущность заключается в том, что те же аффиксы выражают характеристику субъекта действия, которое обозначено исходной глагольной основой: одна и та же лексическая единица (исходная основа) получает различную грамматическую модификацию в связи с различной квалификацией субъекта действия» (Иванов, 1969: 133).

Многими исследователями выдвинута также интерпретация залога, согласно которой его можно отнести «к собственно деривации или приравнять его к ней» (Юлдашев, 1988: 280). Такой подход основан на том факте, что залоговым формам исконно свойственна словообразовательная функция, «оставившая во всех тюркских языках глубокие и неизгладимые следы» (там же: 272). Известный тунгусовед В. В. Болдырев считает, что залоговые формы - это «глагольные основы с различными залоговыми оттенками» (Болдырев, 2007: 530). Г. Д. Санжеев также относил образование залоговых форм в монгольских языках к словообразованию глагола. По его определению, категория залога это «такое оформление глагольной основы, которое показывает отношение действия к субъекту, выраженному подлежащим» (Санжеев, 1963: 19).

Из изложенного выше становится очевидным, что исследователи алтайских языков при любой интерпретации залога обращали внимание как на лексическое значение глагольной основы, так и на значение залоговой морфемы. Такой подход, предлагающий учитывать сочетаемость определенной залоговой глагольной формы с определенными семантическими типами объектов в конечном итоге можно соотнести с теорией валентности. Определение монгольских залоговых форм с такой позиции был предложен Е.А. Кузьменковым: «семантика глагольной лексемы проявляется в валентности глагола, в диатезе образуемой им конструкции» (Кузьменков, 1984: 34).

Категория переходности/непереходности, которая обуславливает характер семантических и синтаксических свойств глагола, естественно привела к пониманию залога как функционально-семантической категории. Как известно,данный подход кисследованию языковыхявлений был предложен А.В.Бондарко (Бондарко, 1999). В работахтакого направления каждая грамматическая форма,в том числе и залоговая, получает характеристику в системе способов выражения определенной семантической категории. В числе тюркологических работ функционально-семантического направления можно назвать исследования К. Б. Доржу по тувинскому залогу (Доржу, 2013), И. В. Шенцовой по шорскому 
глаголу (Шенцова, 1998), 3. И. Саляховой по категории залоговости в башкирском языке (Саляхова, 2012), Н. И. Поповой на материале якутских залоговых конструкций (Попова, 2002). Как видно из изложенного, констатируется наличие в тюркских языках пяти семантических типов отношений между действием и предметом.

Таким образом, различные интерпретации залога, предложенные в результате исследований материала алтайских языков, нацелены на выявление его категориальной сущности, соотношения его с морфологическим, синтаксическим, лексическим уровнями языковой системы. Но в целом правы В. Г. Гузев и Н. Н. Телицин, которые утверждают: «для того, чтобы трактовать категорию залога в разных языках с единых позиций, теоретическое языкознание нуждается в опирающейся на материал разноструктурных языков общей теории залога, включающей понятия залоговая форма и категория, залоговые отношения» (Гузев, Телицин, 2019: 142).

\section{Грамматические формы залога}

Залог в алтайских языках представлен почти одинаковым набором грамматических форм: в тюркских традиционно констатируется пятичленная система, включающая формы основного (или действительного), страдательного, взаимного (или совместно-взаимного), понудительного, возвратного залогов. В тувинском языке также различают пять залогов: основной, понудительный (или побудительный), возвратный, страдательный, совместно-взаимный (Исхаков, Пальмбах, 1961: 273). Как отмечают исследователи, тюркские залоговые формы имеют ясно прослеживаемую «типологическую общность с другими алтайскими языками, что свидетельствует о том, что залог является одной из самых древних категорий тюркского глагола» (Юлдашев, 1988: 269). В. А. Роббек в качестве общей черты языков тунгусо-маньчжурской группы отметил наличие в них действительного и страдательного залогов, а также лексико-грамматической категории возвратности, каузатива, взаимности действия, совместности действия (Роббек, 2007: 240-323). В монгольских языках исследователи фиксируют основной (или прямой), побудительный, совместный, взаимный и страдательный залоги (Санжеев, 1963: 17).

Как видно из изложенного, в тунгусских и монгольских языках, в отличие от тюркских, категории взаимности и совместности действия представлены раздельно, поскольку каждая из них имеет собственный морфологический показатель. Кроме того, исследователи монгольских языков не выделяют в качестве отдельной формы возвратный залог.

Каждая классификационная группа алтайских языков оперирует практически идентичным набором морфологических показателей залоговых отношений. Данная особенность особенно ярко проявляется на примере морфологических показателей каузатива в монгольских и тунгусо-маньчжурских языках. Так, в современном монгольском языке каузативная форма «образуется почти от любого глагола (в том числе и от каузативного же) с помощью суффикса, представленного алломорфами -уул; -лга,-га; -аа с сингармоническими вариантами: -үүл; -лгэ, -лго, -лгө; -гэ, -го, -гө; -ээ, -оо, -өө (Кузьменков, 1984: 37). Для тунгусо-маньчжурского каузатива общим является «наличие общего показателя, возводимого к архетипу *-вукэн» (Роббек, 2007: 296). Тюркологи также отмечают, что «в тюркских языках из всего множества каузативных морфем (общим числом 19) наиболее продуктивным является аффикс -m( $\left.{ }^{\circ}\right)$ p-; чув., як. m(a)p-, все остальные (огуз., кыпч., с-вост., ю-вост.) - -m(b)p-» (Кормушин, 1978: 12). Чередование $-m \sim-p$ в составе каузативного показателя наблюдается в вариантах якутского аффикса побудительного залога -m/-map/-ap/-ыар (Харитонов, 1963: 53), варианты на -m, - , -3 демонстрируют глагольные аффиксы с побудительным значением в башкирском языке (Саляхова, 2012: 66). Тувинская понудительная форма образуется при помощи аффиксов -m, -mыр//-mup, -myp//-myp, - ыp//-up, -yp//- $p$ и целого ряда архаичных морфологических показателей, что показывает схожесть их с общетюркскими показателями. В целом, обращает на себя внимание наличие согласных -t, -r, $-z$, занимающих в приводимых аффиксах ауслаутную позицию.

Единообразие внутри каждой квалификационной группы алтайских языков наблюдается и в составе морфологических показателей пассивных отношений. Так, во всех тюркских языках «форма страдательного залога образуется при помощи аффикса -л, -лл, -ул» (Щербак, 1981: 104). Употребляется также вариант данного аффикса с согласным -н: -(u/ü, i, y/i, e)n (Юлдашев, 1988: 303). Тувинский страдательный залог образует общетюркский аффикс -л (после гласных), -ыл/-ил, -ул/-үл (после согласных) (Исхаков, Пальмбах, 1961: 290). Исследователи отмечают, что некоторые из тюркских языков допускают и другие варианты аффикса: например, якутские -н и -ылын, алтайский -ылыл, турецкий 
-nll/-nil/-nul/-nül. Из изложенного очевидно, в данной группе распространены комбинации показателей - $l$ и - $n$ с гласными разных разрядов. В эвенском языке «формантом страдательного залога» является суффикс -в (Роббек, 2007: 258), в эвенкийском языке выявляется суффикс -в -ву и его фонетические варианты -му, -бу, при помощи которых «образуются непереходные вторичные глагольные основы от основ переходных» (Болдырев, 2007: 535), т. е. это могут быть основы как с пассивным, так и рефлексивным значением. Показатели страдательного залога современного монгольского языка гда/-

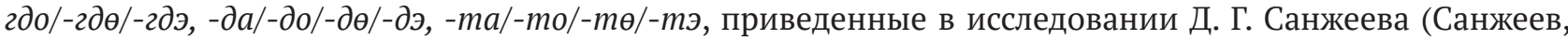
1963: 63), - это алломорфы суффикса -гд (-д, -m) (Кузьменков, 1984: 36), употребление которых регулируется фонетическими правилами.

Категория совместности и взаимности действия в языках алтайского родства в грамматических описаниях представлена по-разному. Так, в грамматиках многих современных тюркских языков залоговая форма с таким значением получила описание под названием «совместно-взаимный залог». Он представлен регулярным аффиксом -ş, который «в монгольских и тунгусо-маньчжурских языках прямых соответствий не имеет» (Юлдашев, 1988: 309). В тунгусо-маньчжурских языках морфологические показатели совместности и взаимности действия также предположительно восходят к одному исходному аффиксу: «генетическая связь морфологических показателей, видимо, не вызывает спора, и они возводятся к архетипу *-лду» (Роббек, 2007: 320). В. Г. Санжеев в своей работе представил показатели взаимного и совместного залогов также отдельно друг от друга: в классическом монгольском взаимный залог обозначается суффиксом -лду/-лде, совместный при помощи -лча/-лчэ, в современном монгольском эти формы представлены, соответственно, суффиксами -лда/-лдо/-лдө/лдэ и -лца/-лцо/-лцө/-лцэ (Санжеев, 1963: 63). Алломорфами универсального показателя представлен рефлексив в алтайских языках. Тюркские языки его значение передают «формой на -un/yn (после конечных согласных в велярном сингармоническом варианте), -ün/-in/-en (после конечных согласных в палатальном сингармоническом варианте), -n (после конечных гласных основы глагола)» (Юлдашев, 1988: 295). В тунгусо-маньчжурских языках рефлексив имеет показатели «эвенк. -в- -n-/-б- -му , -pгa; нег. -в- -n-; уд. -n-; нан. -n-; в маньчжурском и других языках она выражена лексически» (Роббек, 2007: 276). Монгольский рефлексив совмещен с пассивом.

\section{Семантическая характеристика залоговых форм}

Характерной чертой алтайского залога является общность семантики форм в пределах родственных языков. Например, функция побудительной формы глагола в грамматиках тюркских языков определяется как выражение «вмешательства одного субъекта в действие другого» (Кормушин, 1976: 65). Это значение, в свою очередь, может быть определено как «заставлять // велеть // позволять // допускать делать что-л.» (там же). Форма побудительного залога определяется подобным же образом и в монгольских языках: «в отношении побудительного залога, называемого часто также понудительным, причиняющим, переносным, принуждающим и препоручительным, утверждается, что он имеет два значения: ‘заставить кого-л. или позволить кому-л. что-л. сделать'» (Санжеев, 1963: 19). По свидетельству В. А. Роббек, в тунгусо-маньчжурских языках побудительный залог определяется как категория глагола, «единственным значением которого является побуждение другого лица к совершению действия» (Роббек, 2007: 278). Нужно отметить, что многие исследователи отмечают, что «понудительное значение переводит непереходные глаголы в класс переходных» (Рассадин, 1978: 136).

Общим для семантики пассивных построений в алтайских языках является выражение «действия, которому подвергается подлежащее со стороны другого лица» (Котвич, 1962: 197-198). Тюркские пассивные конструкции определяются как синтаксические построения, в которых «подлежащее является ... отнюдь не производителем, а всего лишь носителем-объектом действия» (Юлдашев, 1988: 305). В тунгусо-маньчжурских языках пассивная конструкция имеет аналогичную семантику: «при страдательном залоге глагольный признак воспринимается как направленный на субъект» (Роббек, 2007: 247). Как видно из приведенных цитат, общим для семантики алтайских пассивных конструкций является то, что в них грамматически маркированный субъект высказывания подвергается действию извне.

Все исследователи обращают внимание на многозначность глагольных основ с приведенными выше морфологическими показателями в алтайских языках. Так, в семантической структуре тюркской залоговой формы на -ş усматривается «три основных значения: а) совершение действия сопряженными субъектами по отношению друг к другу (взаимное значение); б) совершение па- 
раллельных однородных действий двумя или несколькими субъектами (совместное значение); в) оказание помощи одного субъекта другому в осуществлении данного действия (значения соучастия в действии) (Юлдашев, 1988: 312). В тувинском совместно-взаимном залоге отмечается два значения: «1) совместное - 'делать что-л. совместно, сообща', 'участвовать (помогать, содействовать совершению какого-либо действия); 2) взаимное - ‘делать что-либо взаимно’» (Исхаков, Пальмбах, 1961: 282). Другими словами, тувинский совместно-взаимный залог передает те же значения, что и во всех тюркских языках. Для монгольского социатива его значение определяется таким же образом: «основное значение социатива - 'совместное действие' - иногда модифицируется как ‘вспомогательное действие', ‘содействие’ (Кузьменков, 1984: 75). Из изложенного видно, что под разными определениями подразумевается множественность как актантов действия, так и самих действий.

В исследованиях по алтайским языкам подчеркивается общность значения страдательного и возвратного залога. О возвратно-страдательном значении аффикса -тын в тофаларском языке писал В. И. Рассадин, продемонстрировав это на примере «көрүн- 'осматривать себя - главным образом в зеркало’, көрдүн- ‘быть видимым, хорошо видным’; овктын- ‘хорошо, легко заряжаться’ - овктаттын‘быть заряженным’» (Рассадин, 1978: 134). В грамматическом описании тувинского языка также обращается внимание на то, что «страдательный залог близок по значению и по форме к возвратному залогу» (Исхаков, Пальмбах, 1961: 290). В тунгусских языках выделяется «страдательно-возвратная» форма с показателем -в (Роббек, 2007: 274). А. Е. Кузьменков заметил, что в современном монгольском языке о «часто встречаются и пассивы с результативным значением. Ср.: хурал нээгдэв - открылось собрание (нээгдэх 'открыться' - пассив от нээх 'открыть'), энд хоёр хадаас зшдаг-даагуй байна - здесь не забиты два гвоздя (хадагдах ‘быть забитым’ - пассив от хадах ‘забивать, прибивать’)» (Кузьменков, 1984: 64).

К широко обсуждаемым в морфологических исследованиях вопросам о многозначности залоговых форм глагола в алтайских языках относится проблема пассивизации каузатива. Так, «в целом ряде алтайских языков каузативные формы глагола могут участвовать в выражении пассивных отношений. Аналогичная особенность каузативных форм отмечена в грамматиках алтайского, хакасского, каракалпакского, а также бурятского и маньчжурского языков» (Кормушин, 1976: 89). Конструкция с таким содержанием формируется при семантической ситуации, когда «кто-либо подвергается действию другого лица в результате своей оплошности, небрежности и вообще проявления пассивности, или когда такое действие почему-либо оказывается для него нежелательным или необходимым, т. е., как бы добровольно допускается “пострадавшим” лицом» (Санжеев, 1963: 42).

Пассивизация семантики каузативной конструкции является результатом изменений в правилах семантической сочетаемости каузативного глагола с определенными типами актантов ситуации в основном по признаку активности/инактивности участников. Как правило, агенсом ситуации выступает природное или стихийное явление, а также предмет, изначально предназначенный для нанесения вреда, ущерба и т. д. Другими словами, агенс всегда активен по отношению к другим актантам ситуации. Кроме того, формированию такой ситуации воздействует лексико-семантическая принадлежность глагольной основы - как правило, каузативные конструкции с пассивным содержанием строятся на базе глаголов с деструктивной семантикой, чаще всего, глаголов физического, иногда температурного воздействия на объект с последующим негативным изменением свойств или состояния пациенса. Обсуждаемые конструкции строятся также на базе глаголов нанесения удара, отрицательного эмоционального и психического воздействия на объект.

\section{Залоговые конструкции}

Языки алтайской типологии, судя по имеющимся исследованиям, в целом совпадают в области синтаксического представления залоговых отношений. Для примера обратимся к каузативным конструкциям, для которых характерно присутствие двух актантов: агенса (субъекта-производителя действия) и пациенса (объекта действия). В анализируемых языках она оформляется в зависимости от переходности/непереходности исходной глагольной основы. В тюркских языках непереходным глаголом формируется каноническая каузативная конструкция, в которой действие выражено побудительной залоговой формой, а пациенс выражен именем в основном, винительном и частном падеже. Ситуация может быть представлена следующими примерами из якутского (як.) и тувинского (тув.) языков: 
(як.)

\begin{tabular}{|c|c|c|c|c|c|c|}
\hline Микиитэ & чэй & и & н & оргу(й)- & т & ap \\
\hline Никита & чай & POSS $^{1}$ & ACC $^{2}$ & кипеть- & CAUS $^{3}$ & 3SG \\
\hline
\end{tabular}

Никита чай свой кипятит

(тув.)

\begin{tabular}{|c|c|c|c|c|c|}
\hline Ава & м & далган & быж- & ыр & ган \\
\hline Мама & POSS & лепешка & жарить- & CAUS & PAST $^{5} / 3 S G$ \\
\hline
\end{tabular}

Мама моя лепешку жарила

Следующим примером можно продемонстрировать эвенские каузативные конструкции, сформированные на основе непереходного глагола:

(эвенк.)

\begin{tabular}{|c|c|c|c|c|c|c|c|}
\hline Д’угурма & мин & у & биракчан & дула & эм- & укэн & ин \\
\hline Тропа & я & ACC & речка & DAT6 & приходить & CAUS & 3SG \\
\hline
\end{tabular}

Тропа меня к речке привела

Монгольские каузативные конструкции от непереходных глаголов имеют такую же структуру, она подразумевает присутствие пациенса, выраженного винительным падежом:

(монг.)

\begin{tabular}{|c|c|c|c|c|c|c|}
\hline Дорж & намай- & $-г$ & өрөө- & -нд & орох- & уулав \\
\hline Дорж & я- & АCC & комната & DAT & входить & CAUS/PRF ${ }^{7}$ \\
\hline
\end{tabular}

Дорж меня в комнату пустил (ввел)

Переходные глаголы часто образуют конструкции с тремя актантами, первый из которых выражается основным падежом, а второй - дательным, третий - инструментальным. Эти конструкции отличаются «прежде всего способом выражения субъекта каузируемого действия: он чаще всего выражается косвенным дополнением, а не прямым, хотя и последнее вовсе не исключается» (Кузьменков, 1984: 43).

Например:

(як.)

\begin{tabular}{|c|c|c|c|c|c|c|c|}
\hline Учуутал & оқо & лор & го & кинигэ & аах- & тар & ap \\
\hline Учитель & ребенок & PL $^{8}$ & DAT & книга & читать & CAUS & PRS $^{9} / 3 S^{-}$ \\
\hline
\end{tabular}

Учитель детям книгу читать велит

(тув.)

\begin{tabular}{|c|c|c|c|c|c|c|c|}
\hline Ава & уру & ун- & -га & өөк & ил- & дир- & ген \\
\hline Мама & дочь & POSS & DAT & пуговица & пришивать- & CAUS & PAST/3SG \\
\hline
\end{tabular}

Мама велела дочери пуговицу прищить

\footnotetext{
${ }^{1} \mathrm{POSS}$ - принадлежность.

${ }^{2}$ ACC - винительный падеж.

${ }^{3}$ CAUS - понудительный залог.

${ }^{4}$ 3SG - 3-е лицо единственного числа.

${ }^{5}$ PAST - форма прошедшего времени.

${ }^{6}$ DAT - дательный падеж.

${ }^{7} \mathrm{PRF}$ - прошедшее время.

${ }^{8} \mathrm{PL}-$ множественное число.

${ }^{9} \mathrm{PRS}$ - настоящее время.
} 
(Монг.)

\begin{tabular}{|c|c|c|c|c|c|c|c|}
\hline Дорж & нохой- & гоороо & нэг & унэг & бари- & ула- & -в \\
\hline Дорж & собака & DAT & одна & лиса & поймать- & CAUS- & -PRF \\
\hline
\end{tabular}

Дорж с помощью своей собаки лису поймал

Одна из самых распространенных в алтайских языках моделей с каузативным содержанием наличие актанта в форме инструментального падежа, который выступает в качестве средства, способа действия, как в примерах:

(як.)

\begin{tabular}{|c|c|c|c|c|c|c|}
\hline Кини & сүгэ & нэн & мас & оэун- & ор & ор \\
\hline Он & топор & INSTR & дерево & падать- & CAUS- & PRS/3SG \\
\hline
\end{tabular}

Он топором дерево валит

(тув.)

\begin{tabular}{|c|c|c|c|c|c|c|c|c|}
\hline Чең & и & биле & дер & и & н & чот- & тун & ган \\
\hline Рукав & POSS & INSTR & пот & POSS & ACC & вытирать- & CAUS & PAST/3SG \\
\hline
\end{tabular}

Рукавом пот вытер

(монг.)

\begin{tabular}{|c|c|c|c|c|c|c|c|}
\hline Би & дайсн & ыг & буу & гаараа & айл- & га & на \\
\hline я & враг & ACC & ружье & INSTR & пугать- & CAUS & PRS/3SG \\
\hline
\end{tabular}

Я врага своим ружьем пугаю

Пассивные конструкции, которые строятся на базе формы страдательного залога переходного глагола, употребляются во всех рассматриваемых языковых группах. Но эти построения имеют отличия в оформлении - в языках тюркской группы собственно-пассивные конструкции не имеют выраженного агенса, но часто - выраженный объект-пациенс. Приведем примеры:

(тув.)

\begin{tabular}{|c|c|c|c|}
\hline Сиген & кес- & тин & ген \\
\hline сено & косить- & PASS & PAST/3SGF \\
\hline
\end{tabular}

Сено скошено

(тур.)

\begin{tabular}{|c|c|c|c|}
\hline Ağaç & kes- & il & di \\
\hline Дерево & рубить- & PASS & PRF $/ 3^{3}$ SG \\
\hline
\end{tabular}

Дерево срублено

В тунгусских языках, как правило, пассивные конструкции представляют собой трехчленные агентивные построения, в которых пациенс, как и в тюркских языках, выражен именем в основном падеже. При этом агенс выражен формой дательного падежа, что отметил В. А. Роббек в эвенском языке (Роббек, 2007: 255). В целом, тунгусо-маньчжурские собственно-пассивные конструкции формируются по модели, в которой выражены и агенс, и пациенс. Это можно продемонстрировать на примере эвенской конструкции:

\footnotetext{
${ }^{1}$ INSTR - орудный падеж.

${ }^{2} \mathrm{PASS}$ - страдательный залог.

33 - третье лицо.
} 
(эвен.)

\begin{tabular}{|c|c|c|c|c|c|c|}
\hline Буйун & гиркари & ду & д’эбэ & в & рэ & н \\
\hline Олень & волк & DAT & кушать- & PASS & PRS & 3SG \\
\hline
\end{tabular}

Олень волком съедается

По такой же модели формируются пассивные конструкции в монгольских языках:

(монг.)

\begin{tabular}{|c|c|c|c|c|c|}
\hline Төмөр & зэвэн & д & идэ- & гд & сэн \\
\hline Железо & жавчина & DAT & есть- & PASS & PSPT $^{1}$ \\
\hline
\end{tabular}

Железо ржавчиной изъедено

В тувинском языке, как во всех других тюркских языках, ситуации подобного содержания формируются конструкциями с агенсом в форме инструментального падежа. Они имеют семантическое ограничение - употребляются в ситуациях, когда в роли пациенса выступает инактивный неодушевленный предмет, а предикатом, обозначающим действие, выступает глагол активного действия. Такие конструкции, как правило, выражают естественные ситуации, происходящие в природе. К примеру:

(тув.)

\begin{tabular}{|c|c|c|c|c|c|}
\hline Чер & хар & биле & шып & тын & ган \\
\hline Земля & снег & INSTR & покрывать- & PASS & PAST/3SG \\
\hline
\end{tabular}

Земля снегом покрылась

Следующие примеры демонстрируют характерные для всех рассматриваемых групп языков так называемые случаи пассивизации каузатива. Они представлены конструкциями, «в которых в силу определенных денотативных условий действие распространяется на каузатора» (Кормушин, 1978: 82). Конструкцию такого содержания можно представить в якутских предложениях типа:

(як.)

\begin{tabular}{|c|c|c|c|c|c|c|}
\hline Мин & ардах & ха & баттаа- & т & т & -ым \\
\hline Я & дождь & DAT & задавить & CAUS & PRF & $1^{14}$ SG \\
\hline
\end{tabular}

Я под дождь попал (букв.: дождем я задавлен).

Конструкции с таким содержанием выявляют и в монгольских языках:

(монг.)

\begin{tabular}{|c|c|c|c|c|c|}
\hline Би & зэгий & д & хатг & уула & в \\
\hline Я & пчела & DAT & ужалить & CAUS & PRF/1SG \\
\hline
\end{tabular}

Меня ужалила пчела (букв.: я пчеле ужалить себя дал).

О семантической структуре вышеприведенных конструкций речь шла выше. Примеры демонстрируют ситуации, сформированные на базе глаголов с деструктивной семантикой, это глаголы со значением баттаа - ‘давить', хатгах - ‘ужалить'.

При анализе морфологического оформления тех или залоговых отношений, видимо, нужно иметь в виду, что в некоторых случаях одна и та же конструкция может у разных авторов получать разное семантическое толкование. Причина этого - в разных теоретических подходах к проблеме глагольного залога в целом.

${ }^{1} \mathrm{PSPT}$ - причастие прошедшего времени. 


\section{Заключение}

Таким образом, залоговые формы представляют собой одну из важнейших категорий глагола, которая к настоящему времени в системе каждой языковой группы алтайских языков утвердилась с почти одинаковым набором грамматических форм. Очевидно, что в алтаистике еще не выработана общая теория залога с учетом всех грамматических и структурно-семантических особенностей залоговых форм и формируемых ими синтаксических конструкций. Еще одной характерной чертой алтайского залога является общность семантики форм в пределах родственных языков. Исследование форм глагольного залога осложняется тем, что почти все они полисемичны, а некоторые из них имеют общее происхождение и значение. Такой характер залоговых форм и образуемых на их базе конструкций ставит необходимость поиска разных способов и подходов, которые позволили бы дать возможно более объективное описание семантики залоговых конструкций.

\section{СПИСОК ЛИТЕРАТУРЫ}

Болдырев, Б. В. (2007) Морфология эвенкийского языка. Новосибирск : Наука. 932 с.

Бондарко, А. В. (1999) Основы функциональной грамматики: Языковая интерпретация идеи времени. СПб. : Изд-во СПбГУ. 260 с.

Винокурова, Н.И. (2016) Глоссирование как метод репрезентации текстов в якутском языке // Северо-Восточный гуманитарный вестник. № 4(17). С. 85-99.

Гузев, В. Г., Телицин, Н. Н. (2019) Турецкие залоги и понятие «залог» // Sözüm munda qalïr, barïr bu özüm. Scripta in memoriam D. M. Nasilov : коллективная монография. М. : ООО «Изд-во МБА». 399 с. C. $134-144$.

Доржу, К. Б. (2013) Категория залога в тувинском языке. Кызыл : РИО ТувГУ. 150 с.

Иванов, С. Н. (1969) Родословное древо тюрок Абу-л-гази-хана. Грамматический очерк (Имя и глагол. Грамматические категории). Ташкент : Изд-во «ФАН» Узбекской ССР. 202 с.

Исхаков, Ф. Г., Пальмбах, А. А. (1961) Грамматика тувинского языка. Фонетика и морфология. М. : Изд-во восточной литературы. 472 с.

Кормушин, И. В. (1976) О пассивном значении каузативных глаголов // Turcologica. К семидесятилетию академика А. Н. Кононова / отв. ред. С. Г. Кляшторный, Ю. А. Петросян, Э. Р. Тенишев. Ленинград : Наука. 363 с. С. 89-93.

Кормушин, И. В. (1978) Каузативные формы глагола в алтайских языках // Очерки сравнительной морфологии алтайских языков / отв. ред. О. П. Суник совм. с Д. М. Насиловым, О. П. Суником, В. И. Цинциус и Н. И. Летягиной. Л. : Наука. 270 с. С. 10-87.

Котвич, Вл. (1962) Исследование по алтайским языкам: пер с польского. М.: Изд-во иностр. лит-ры. $370 \mathrm{c}$.

Кузьменков, Е. А. (1984) Глагол в монгольском языке. Ленинград: Изд-во ЛгУ. 138 с.

Попова, Н. И. (2002) Категория залога в контексте теории синтаксической деривации // Тюркские и северные языки / отв. ред. П. А. Слепцов. Якутск: Ин-т гум. исслед. АН РС (Я). 334 с. С. 148-158.

Рассадин, В. И. (1978) Морфология тофаларского языка в сравнительном освещении. М.: Наука. 286 с.

Роббек, В. А. (2007) Грамматические категории эвенского глагола в функционально-семантическом аспекте. Новосибирск: Наука. 726 с.

Саляхова, 3. И. (2012) Залог глагола и залоговость: история и современность. Уфа: Гилем. 140 с.

Санжеев, Г. Д. (1963) Сравнительная грамматика монгольских языков. Глагол. М. : Наука. 266 с.

Харитонов, Л. Н. (1963) Залоговые формы глагола в якутском языке. М. ; Л. : Изд-во АН СССР. 124 с.

Шенцова, И. В. (1998) Шорский глагол. Функционально-семантическое исследование : автореф. дис. ... д-ра. филол. наук. М. 48 с.

Щербак, А. М. (1981) Очерки по сравнительной морфологии тюркских языков (Глагол). Ленинград : Наука; Ленинградское отделение. 176 с.

Юлдашев, А. А. (1988) Категория залога // Сравнительно-историческая грамматика тюркских языков. Морфология / отв. ред. Э. Р. Тенишев. М. : Наука. 557 с. С. 269-309. 


\section{REFERENCES}

Boldyrev, B. V. (2007) Morfologiia evenkiiskogo iazyka [Morphology of the Evenki language]. Novosibirsk, Nauka Publ. 932 p. (In Russ.).

Bondarko, A. V. (1999) Osnovy funktsional'noi grammatiki: Iazykovaia interpretatsiia idei vremeni [Functional Grammar Basics: Linguistic Interpretation of the Idea of Time]. St. Petersburg, SPbGU. 260 p. (In Russ.).

Vinokurova, N. I. (2016) Glossirovanie kak metod reprezentatsii tekstov v iakutskom iazyke [Glossing as a method of representing texts in Yakut language]. Severo-vostochnyi Gumanitarnyi Vestnik. Vol 4 (17). Pp. 85-99. (In Russ.).

Guzev, V. G. and Telitsin, N. N. (2019) Turetskie zalogi i poniatie «zalog» [Voice in Turkish and the concept of grammatical voice]. In: «Sözüm munda qalï, barïr bu özüm». Scripta in memoriam D. M. Nasilov [«My word stays here, i'm leaving». Type in memoriam D. M. Nasilov]. Moscow, OOO «Izd-vo MBA». 399 p. Pp. 134-144. (In Russ.).

Dorzhu, K. B. (2013) Kategoriia zaloga v tuvinskom iazyke [The category of voice in Tuvan language]. Kyzyl, RIO TuvGU. 150 p. (In Russ.).

Ivanov, S. N. (1969) Rodoslovnoe drevo tiurok Abu-l-gazi-khana. Grammaticheskii ocherk (Imia i glagol. Grammaticheskie kategorii) [Family tree of the Turks by Abu-l-ghazi-khan. An Essay on Grammar (The name and the verb. Grammatical categories)]. Tashkent. Publishing house "FAN" of the Uzbek SSR. 202 p. (In Russ.).

Iskhakov, Ph. G. and Pal'mbakh, A. A. (1961) Grammatika tuvinskogo iazyka. Fonetika i morfologiia [A grammar of the Tuvan language. Phonetics and morphology]. Moscow, Vostochnaia literature Publ. 472 p. (In Russ.).

Kormushin, I.V. (1976) O passivnom znachenii kauzativnykh glagolov [On the passive meaning of causative verbs]. In: Turcologica. K semidesiatiletiiu akademika A.N. Kononova. [Turkology. On the occasion of the seventieth birthday of academician A. N. Kononov]. Ed. by S. G. Klyashtorny, Yu. A. Petrosyan and E. R. Tenishev. Leningrad, Nauka Publ. 363 p. Pp. 89-93. (In Russ.).

Kormushin, I. V. (1978) Kauzativnye formy glagola v altaiskikh iazykakh [Causative verb forms in Altai languages]. In: Ocherki po sravnitel'noi morfologii altaiskikh iazykov [Essays on the comparative morphology of Altai languages]. Ed. by O. P. Sunik with D. M. Nasilov, O. P. Sunik, V. I. Tsintsius and N. I. Letiagina. Leningrad, Nauka Publ. 270 p. Pp. 10-87. (In Russ.).

Kotvich, Vl. (1962) Issledovanie po altaiskim iazykam [A Study of Altai Languages]: Translated from Polish. Moscow, Izdatel'stvo inostrannoi literatury. 370 p. (In Russ.).

Kuz'menkov, E. A. (1984) Glagol v mongol'skom iazyke [The Verb in Mongolian]. Leningrad, LGU Publ. 138 p. (In Russ.).

Popova, N. I. (2002) Kategoriia zaloga v kontekste teorii sintaksicheskoi derivatsii [The category of voice in the context of syntactic derivation theory]. In: Tiurkskie i severnye iazyki [Turkic and northern languages]. Ed. by P. A. Sleptsov. Yakutsk, In-t gum. issled. AN RS (Ia). 334 p. Pp. 148-158. (In Russ.).

Rassadin, V. I. (1978) Morfologiia tofalarskogo iazyka v sravnitel'nom osveshchenii [A Comparative Study of the Morphology of Tofalar Language]. Moscow, Nauka Publ. 286 p. (In Russ.).

Robbek, V. A. (2007) Grammaticheskie kategorii evenskogo glagola v funktsional'no-semanticheskom aspekte [The Grammatical Categories of the Evenki Verb in the Functional and Semantic Aspect]. Novosibirsk, Nauka Publ. 726 p. (In Russ.).

Saliakhova, Z. I. (2012) Zalog glagola i zalogovost': istoriia i sovremennost' [The Verbal Voice: History and Present]. Ufa, Gilem. 140 p. (In Russ.).

Sanzheev, G. D. (1963) Sravnitel'naia grammatika mongol'skikh iazykov. Glagol [A Comparative Grammar of the Mongolian Languages. The Verb]. Moscow, Nauka Publ. 266 p. (In Russ.).

Kharitonov, L. N. (1963) Zalogovye formy glagola v iakutskom iazyke [Forms of Verbal Voice in Yakut Language]. Moscow, Leningrad, Izd-vo AN SSSR. 124 p. (In Russ.).

Shentsova, I.V.(1988) Shorskii glagol. Funktsional'no-semanticheskoe issledovanie [The Verb in Shor Language: A Functional and Semantic Study]. Abstract of Dissertation ... Doctor of Philology. Moscow. 48 p. (In Russ.).

Shcherbak, A. M. (1981) Ocherki po sravnitel'noi morfologii tiurkskikh iazykov (Glagol) [Essays on the Comparative Morphology of Turkic Languages: The Verb]. Leningrad, Nauka Publ, Leningradskoe otdelenie. 176 p. (In Russ.).

Iuldashev, A. A. (1988) Kategoriia zaloga [The Category of Verbal Voice]. In: Sravnitel'no-istoricheskaia grammatika tiurkskikh iazykov. Morfologiia [A Comparative Historical Grammar of Turkic Languages: Morphology]. Ed. by E. R. Tenishev. Moscow, Nauka. 557 p. Pp. 269-309. (In Russ.). 